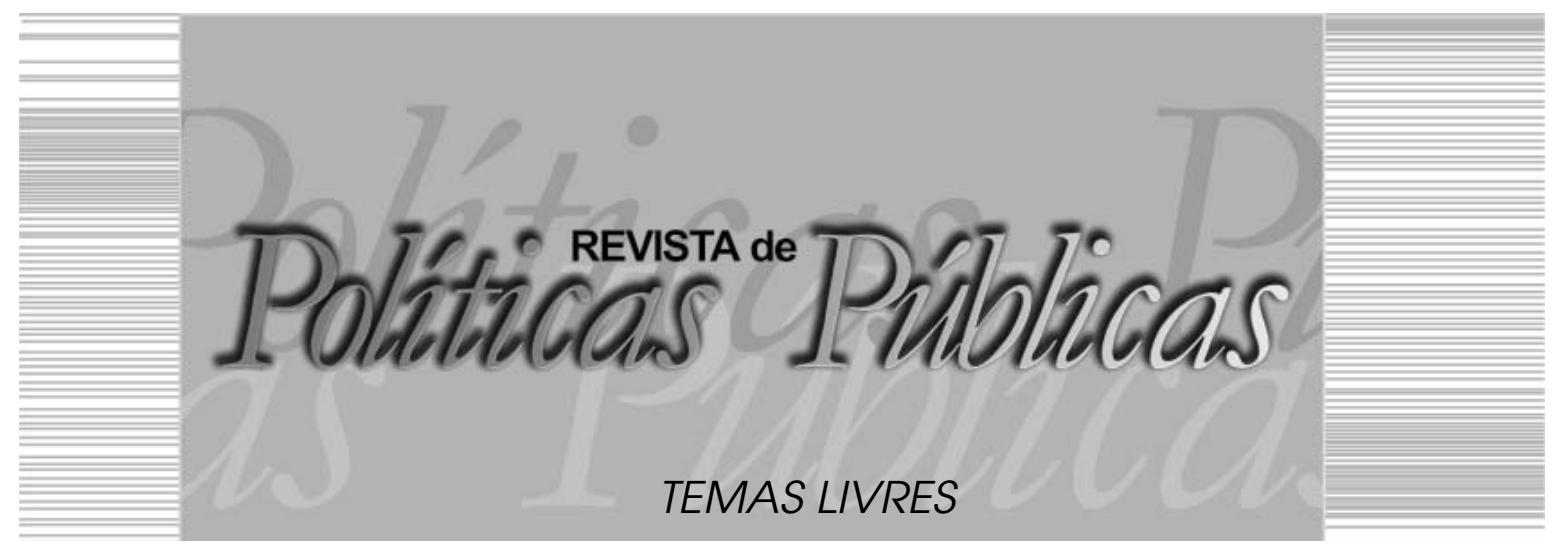

\title{
A VIDA DE MARX NO TEMPO DOS GRUNDRISSE: notas biográficas entre 1857 e $1858^{1}$
}

\author{
Marcello Mustol \\ York University
}

\section{Resumo}

A crise econômica de 1856-58 estimulou Marx a retomar seus estudos de economia política com vistas a dotar o movimento operário e socialista de um instrumental teórico capaz de fundamentar a ação política de superação da ordem social do capital. Numa situação pessoal de extrema dificuldade, convivendo com a pobreza, a doença e dificuldades de toda ordem, apesar da ajuda permanente de Engels, Marx elaborou neste período nada menos que os Grundrisse e Para a crítica da Economia Política, fundamentos da perspectiva teórica que mais tarde se desdobraria n'O Capital.

Palavras-chave: Revolução, crítica da economia política, crise econômica.

THE LIFE OF MARX IN GRUNDRISSE TIMES: bibliographic notes between 1857 and 1858

\begin{abstract}
The economic crisis of 1856-1858 encouraged Marx to resume his studies about political economy in order to prepare the socialist worker movement with a theoretical instrument able to substantiate the political action to overcome the capital's social order. Despite his own very difficult situation, which was characterized by poverty, disease and another problems, Marx was able to write

\footnotetext{
Filosófo. Doutor em Filosofia e Política. Professor Associado do Departamento de Sociologia da York University . E-mail: marcello.musto@googlemail.com / York University, 4700 Keele Street, Toronto, ON, Canada M3J 1P3
} 
works like Grundrisse and A Contribution to the Critical of Political Economy, basis of a theoretical perspective that would unfold later in Capital.

Key words: Revolution, critique of political economy, economic crisis.

\section{NAMORANDO A REVOLUÇÃO}

Em 1848, a Europa foi sacudida por uma sucessão de numerosas insurreições populares inspiradas pelos princípios da liberdade política e da justiça social. A fraqueza de um movimento operário recém-nascido, a renúncia a estes ideais por parte da burguesia, os quais ela havia compartilhado quando do seu surgimento, a repressão militar violenta e o retorno da prosperidade econômica geraram a derrota da sublevação em todos os lugares e as forças da reação reconquistaram os dominíos do poder estatal com firmeza.

Marx apoiou as insurreições populares a partir do diário Neue Rheinische Zeitung: Organ der Demokratie, no qual, ele era fundador e editor chefe. Das colunas do jornal ele realizou intensa atividade de agitação apoiando a causa dos insurgentes e conclamando o proletariado a promover a Revolução Social e Republicana (MARX, 1977, tradução nossa)2. Naquele período, ele vivia entre Bruxelas, Paris e Colônia e viajava para Berlim, Viena e Hamburgo bem como para muitas outras cidades alemãs, estabelecendo novas conexões para fortalecer e desenvolver lutas em desdobramento. Por causa desta incansável atividade militante ele foi condenado à expulsão, primeiro da Bélgica, depois da Prússia e quando o novo governo da França sob a presidência de Luis Bonaparte exigiu que ele deixasse Paris, ele decidiu se mudar para a Inglaterra. Ele chegou lá no verão de 1849, aos 31 anos de idade para se fixar em Londres. Inicialmente estava convencido de que ficaria por pouco tempo; acabou vivendo lá, expatriado, pelo resto da vida.

Os primeiros anos de seu exilio inglês foram marcados pela mais profunda condição de pobreza e agravamento da saúde que contribuiu para a perda trágica de três dos seus filhos. Embora a vida de Marx nunca foi fácil, este período foi certamente seu pior estágio. Entre dezembro de 1850 e setembro de 1856 ele viveu com sua familia em uma casa conjugada de dois quartos, no numero 28 da Dean Street em Soho, uma das áreas mais pobres e deterioradas da cidade. A herança obtida por sua esposa Jenny Von Westphalen com a morte do tio e da mãe dela, inesperadamente deu a eles uma centelha de esperança e permitiu a ele quitar suas muitas dívidas, re- 
tirar suas roupas e objetos pessoais da penhora e direcionar a coisas mais prementes.

No outono de 1856, Marx, sua esposa e suas três filhas Jenny, Laura e Eleanor, juntamente com sua leal criada Helene Demuth que era parte integral da familia - se mudaram para os subúrbios a nordeste de Londres, no número 9, Gratfton Terrace Kentish Town, onde o aluguel tinha preço mais acessível. A casa em que permaneceram até 1864, era construída em um lugar recém criado que não tinha estrada nem ligação com o centro e completamente escura à noite. Mas finalmente ele vivia em uma casa de verdade, reunia as condições mínimas para a família para manter "[...] ao menos uma aparência de respeitabilidade.” (MARX, 1970, p. 223, tradução nossa) $)^{3}$.

Ao longo do ano de 1856, Marx negligenciou completamente o estudo da economia política, mas a aproximação de uma crise financeira internacional mudou esta situação repentinamente. Em um clima de profunda incerteza que se transformou em pânico generalizado assim contribuindo para uma quebradeira em todos lugares, Marx sentiu que mais uma vez a hora certa para a ação havia chegado e prevendo o futuro desenvolvimento da recessão escreveu a Engels "Eu creio que não seremos capazes de ficar aqui muito tempo apenas assistindo." (MARX; ENGELS, 1983, p. 70, tradução nossa) ${ }^{4}$. Engels, sempre com grande otimismo previu o seguinte cenário:

"Desta vez haverá um dia de cólera sem precedente; a indústria da Europa inteira está em ruinas [...] todos os mercados saturados, toda a classe dominante na sopa, completa quebradeira da burguesia, guerra e desordem em temperatura elevada. Eu, também, acredito que de um tudo vai acontecer em 1857." (MARX; ENGELS 1983, p. 72) $)^{5}$.

Ao final de uma década que tinha visto o refluxo do movimento revolucionário e no curso da qual Marx e Engels foram impedidos de participar ativamente na arena política europeia, os dois começaram a trocar mensagens com uma renovada confiança nas perspectivas para o futuro. A longa espera pelo envolvimento com a revolução parecia agora próximo de acabar, e para Marx isto apontava para uma prioridade acima de todas: sintetizar sua ciência econômica e finalizar seus estudos o mais breve possível. 


\section{LUTANDO CONTRA A MISÉRIA E A DOENÇA}

Para conseguir se dedicar ao trabalho nessa condição, Marx precisa de alguma tranquilidade, mas sua situação pessoal não permitia a ele nenhuma trégua. Depois de ter usado todos os recursos à sua disposição na relocação de uma nova casa, ele novamente estava sem dinheiro para pagar o aluguel do primeiro mês. Então ele relatou a Engels, que morava em Manchester na época, todos os infortúnios de sua situação.

"[Eu estou] sem perspectivas e com muitas contas a vencer. Eu não tenho idéia sobre o que fazer e, na verdade, minha situação é mais desesperadora do que há cinco anos atrás. Eu pensei que já tivesse experimentado a quintessência dessa situação deplorável, mas ainda não acabou.” (MARX; ENGELS, 1983, p. 93) .

Esse relato deixou Engels profundamente chocado, pois ele tinha certeza que depois da mudança seu amigo estaria finalmente melhor acomodado, então em janeiro de 1857, ele gastou o dinheiro recebido de seu pai no natal para comprar um cavalo e buscar sua grande paixão: a caçada à raposa. Entretanto, durante este período e por toda a sua vida, Engels nunca negou todo apoio a Marx e sua família e se preocupou com essa difícil conjuntura; ele enviava a Marx cinco libras por mês e cobrou de Marx para contar com ele sempre nos momentos difíceis.

O papel de Engels, certamente não era limitado a fornecer suporte financeiro. No profundo isolamento em que Marx viveu durante aqueles anos, mas pela larga correspondência trocada entre os dois, Engels era o único ponto de referência com quem ele podia travar um debate intelectual, "[...] mais do que qualquer coisa eu preciso de sua opinião." (MARX; ENGELS, 1983, p. 303, tradução nossa)7. Engels era o único amigo a quem confidenciar em tempos difíceis de desespero: "Escreva logo porque suas cartas são essenciais agora para ajudar a me animar. A situação está difícil.” (MARX; ENGELS, 1983, p. 106, tradução nossa) ${ }^{8}$. Marx era também a companhia com quem compartilhava o sarcasmo despertado pelos acontecimentos: "Eu invejo as pessoas que plantam bananeira. Deve ser uma boa maneira de montar a cabeça da burguesia raivosa e cheia de merda." (MARX; ENGELS, 1983, p. 99, tradução nossa) ${ }^{9}$.

Na verdade, a incerteza logo tornou-se mais urgente. A única renda de Marx, além da ajuda dada por Engels, consistia de pa- 
gamentos recebidos do New York Tribune, o jornal em inglês de maior circulação naquele tempo. $\mathrm{O}$ acordo sobre suas contribuições, pelas quais receberia 2 libras por artigo, mudou com a crise econômica que também havia repercutido no diário norte-americano. Com exceção do viajante e escritor americano Bayard Taylor, Marx foi o único correspondente europeu que não foi demitido, mas suas participações diminuíram de dois artigos por semana para um, e "[...] contudo nos tempos de prosperidade, eles nunca me deram um centavo a mais." (MARX; ENGELS, 1983, p. 374, tradução nossa) ${ }^{10}$ - seus pagamentos eram divididos. Marx de forma sarcástica relatou o acontecimento: "Há uma certa ironia do destino no fato de eu estar envolvido por esta maldita crise." (MARX; ENGELS, 1983, p. 198 $)^{11}$. Entretanto, poder testemunhar a derrocada financeira foi um entretenimento sem igual: "É interessante que os capitalistas que vociferavam contra o 'direito ao trabalho', estarem agora, em todos os lugares, exigindo 'apoio público' de seus governos e [...] então advogando o 'direito de lucrar' às custas do dinheiro público." (MARX; ENGELS, 1983, p. 214, grifo dos autores, tradução nossa) ${ }^{12}$. Apesar de seu estado de ansiedade, ele comunicou a Engels que "Embora minha situação financeira possa estar apertada de fato, nunca desde de 1849, me senti tão confortável como durante esta convulsão." (MARX; ENGELS, 1983, p. 199) $)^{13}$.

O começo de um novo projeto editorial aliviou a situação de desespero. O editor do New York Tribune, Charles Dana, convidou Marx a se juntar ao comitê editorial para a Nova Enciclopédia Americana. A falta de dinheiro o levou a aceitar a oferta, mas ele confiou a maior parte do trabalho a Engels para dedicar mais tempo à sua pesquisa. Na divisão de trabalho deles, entre 1857 e 1860, Engels editou verbetes militares - a maioria dos quais haviam sido solicitados - enquanto Marx compilava vários esboços biográficos. Embora o pagamento de duas libras por página era muito baixo, ainda assim, era um complemento ao seu estado financeiro desastroso. Por esta razão Engels o conclamou (ele) a conseguir o maior número de verbetes possíveis de Dana. "Nós podemos oferecer aquela quantidade de 'pura' erudição enquanto o ouro puro da Califórnia pagar por isto." (MARX; ENGELS, 1883, p. 122) ${ }^{14}$. Marx seguiu o mesmo princípio para escrever seus artigos: "para ser o mais conciso quanto é possível, enquanto isto não significar idiotice." (MARX; ENGELS, 1983, p. 272) $)^{15-16}$. 
Em que pese os esforços, sua situação financeira não melhorou de modo algum. Na realidade ficou tão insustentável que, procurado por agiotas que ele comparou a lobos famintos (MARX; ENGELS, 1983, p. 214) $)^{17}$, e na ausência de carvão para se aquecerem durante o frio inverno daquele ano, em janeiro de 1858 ele escreveu a Engels: "Se esta situação persistir, é mais provável que serei enterrado em uma cova bem funda do que continuar vegetando desta maneira. Sendo sempre um aborrecimento para os outros e, além disso, sendo constantemente atormentado por ninharias pessoais torna-se, no final das contas, insuportável." (MARX; ENGELS, 1983, p. 255 $)^{18}$. Nestas circunstancias ele também tinha palavras amargas para o campo emocional: "Reservadamente, penso que levo a vida mais agitada possível de se imaginar [...] para pessoas com grandes aspirações nada é mais estúpido do que se casar e deixar se levar pelas pequenas misérias da vida doméstica e privada." (MARX; ENGELS, 1983, p. 273, tradução nossa) ${ }^{19}$.

A pobreza não era o único espectro rondando Marx. Como a parte maior de sua vida atribulada, ele também foi acometido naquele período por várias enfermidades. Em março de 1857 o trabalho excessivo feito à noite lhe deixou com uma infecção no olho; em abril ele teve dor de dente; em maio se queixava constantemente do fígado, por conta deste último, ele se afundou em remédios. Enfraquecido, ficou incapacitado, sem poder trabalhar por três semanas. Ele então, relatou a Engels:

\begin{abstract}
Para não perder o tempo todo, eu, na ausência de coisas melhores, tenho estudado a língua dinamarquesa; entretanto, se as promessas do médico estiverem corretas, tenho perpectivas de me tornar um ser humano novamente já na próxima semana. Enquanto isto estou tão amarelo quanto um marmelo e muito mais irritado. (MARX; ENGELS, 1883, p. 132) ${ }^{20}$.
\end{abstract}

Logo em seguida, uma ocorrência mais grave atingiu a família Marx. No início de julho Jenny deu a luz ao último filho do casal, mas o bebê, nasceu muito fraco, morreu logo após o parto. Enlutado mais uma vez, Marx confessou a Engels: "O acontecimento em si não é uma tragédia. Mas [...] as circunstâncias que a causaram foram tais que fez relembrar memórias dolorosas (provavelmente a morte de Edgar (1847-55), o último filho que ele havia perdido). É impossível discutir sobre isto em uma carta." (MARX; ENGELS, 1983 , p. 143 ${ }^{21}$. Engels ficou muito comovido com esta declaração e respondeu: "[...] tudo deve ser muito difícil para você escrever desse 
modo. Você pode aceitar a morte da pequenina de modo estóico, mas sua esposa dificilmente aceitará assim também." (MARX; ENGELS, 1983, p. 143) ${ }^{22}$.

A situação, posteriormente, complicou-se ainda mais pelo fato de que Engels ficou doente e foi seriamente afetado por uma febre nas glândulas, de modo que ele não conseguiu trabalhar durante o verão inteiro. Nessa altura dos acontecimentos, Marx enfrentou sérias dificuldades. Sem os verbetes para a enciclopédia feitas por seu amigo, ele precisou ganhar tempo, portanto, fingiu ter enviado uma pilha de manuscritos a Nova York e que os mesmos tinha sido perdidos pelo correio. No entanto, a pressão não diminuiu. Quando os acontecimentos envolvendo a rebelião dos Cipaios na India tornou-se mais intensa, o New York Tribune ficou na expectativa por uma análise de seu especialista, sem saber que os artigos a respeito de assuntos militares eram, na verdade, trabalho de Engels. Marx forçado pelas circunstâncias a se encarregar temporariamente do departamento militar (MARX; ENGELS, 1983, p. 249)23 se aventurou a afirmar que os Ingleses precisavam bater em retirada no início da estação chuvosa. Ele informou a Engels sobre sua escolha com as seguintes palavras: "[...] é possível que eu venha a parecer muito ruim, mas de qualquer forma com um pouco de dialética eu poderei sair dessa. Naturalmente, eu formulei minhas palavras para acertarem de um modo ou de outro." (MARX; ENGELS, 1983, p. 152) ${ }^{24}$. Entretanto, Marx não subestimou este conflito e, refletindo sobre seus possíveis efeitos, disse "Com a perspectiva de que muitos homens sejam arrastados pelo conflito e os milhões que ela custará para a Inglaterra, a Índia tornou-se agora nosso melhor aliado." (MARX; ENGELS, 1983, p. 249) 25.

\subsection{ESCREVENDO OS GRUNDRISSE (DER KRITIK DER POLITISCHEN ÖKONOMIE: ROHENTWURF) ${ }^{26}$}

Pobreza, problemas de saúde e todos os tipos de privações - os Grundrisse foram escritos neste trágico contexto. Não foi o produto de um pensador no bem estar protegido pela tranqüilidade burguesa; pelo contrário, foi um trabalho de um autor que experimentou dificuldade e encontrou energia para prosseguir sustentado somente na crença de que, com o avanço da crise econômica, seu trabalho tornou-se necessário à sua época: "Eu estou trabalhando como louco, noite adentro, para reunir meus estudos de economia para que possa 
ao menos compreender os contornos claramente antes do dilúvio." (MARX; ENGELS, 1983, p. 217) ${ }^{27}$.

No outono de 1857, Engels estava avaliando os acontecimentos com otimismo: "A quebradeira americana é excelente e vai demorar a passar [...] o comércio novamente vai ladeira abaixo pelos próximos três ou quatro anos. Agora temos uma chance." (MARX; ENGELS, 1983, p. 195, tradução nossa)28. Dessa maneira ele estava encorajando Marx: "[...] em 1848 nós dizíamos: agora nossa hora chegou, e em certo sentido, era verdade, mas desta vez está acontecendo mesmo e é um caso de vida ou morte." (MARX; ENGELS, 1983 , p. 200, tradução nossa)29. Por outro lado, sem ter qualquer dúvida sobre a iminência da revolução, ambos esperavam que ela não entrasse em erupção antes que toda a Europa tivesse sido tomada pela crise, e portanto as perspectivas para o "ano de luta" foram adiadas para 1858 (MARX; ENGELS, 1983, p. 236) ${ }^{30}$.

Conforme relato em uma carta de Jenny von Westphalen para Conrad Schramm, um amigo da família, a crise geral teve um efeito positivo sobre Marx: "Você consegue imaginar o quão animado está o Mouro. Ele recuperou todo o seu ritual habitual e disposição para trabalhar bem como a vivacidade e espirituosidade." (MARX; ENGELS, 1983, p. 566) ${ }^{31}$. Na verdade, Marx começou um período de intensa atividade intelectual, dividindo seu trabalho entre os artigos para o New York Tribune, o trabalho para a Nova Enciclopédia Americana, o projeto inacabado de escrever um panfleto sobre a crise e obviamente, os Grundrisse. Entretanto, apesar de sua energia renovada, todos esses empreendimentos mostraram-se excessivos e a ajuda de Engels tornou-se mais uma vez indispensável. No início de $1858, \operatorname{logo}$ em seguida a sua completa recuperação da doença que havia sofrido, Marx pediu a ele que retornasse a trabalhar nos verbetes para a enciclopédia:

[...] às vezes, me parece que se você puder se organizar para fazer um pouco de seções a cada dois dias, isto poderia talvez funcionar como um freio para sua bebedeira que, pelo que eu sei de Manchester e no momento de excitação que estamos vivendo atualmente, parece inevitável e não te faz nenhum bem [...] porque eu realmente preciso terminar minhas outras tarefas que estão roubando todo o meu tempo, ainda que a casa desabe sobre a minha cabeça! (MARX; ENGELS, 1983, p. 238, tradução nossa) ${ }^{32}$.

Engels aceitou a exortação entusiasmada de Marx e reafirmou que, após os feriados, ele "[...] experimentaria uma vida mais tran- 
quila e mais produtiva." (MARX; ENGELS, 1983, p. 239, tradução nossa) ${ }^{33}$. Contudo, o maior problema de Marx ainda era a falta de tempo e ele repetidamente reclamava ao seu amigo que "[...] toda vez que eu estou no Museu (Britânico), há tanta coisa que eu preciso procurar, a hora de fechar (agora $4 \mathrm{~h}$ da tarde) chega, antes que sequer eu tenha vasculhado o lugar. E ainda tem aquela jornada lá. Tanto tempo perdido!" (MARX; ENGELS, 1983, p. 258, tradução nossa) $)^{34}$. Além disso, juntamente com as dificuldades práticas, há outras de natureza teórica: "Eu tenho sido [...] tão desafortunadamente assaltado por erros nos cálculos que, de tanto desespero, tenho me aplicado a uma revisão da álgebra. A aritmética sempre foi minha inimiga, mas dando uma volta pela álgebra, rapidamente voltarei ao curso das coisas." (MARX; ENGELS, 1983, p. 244, tradução nossa $)^{35}$.

Por fim, seus escrúpulos contribuíram para diminuir o rítmo da escrita dos Grundrisse, pois ele exigia de si mesmo que mantivesse a pesquisa de novas provas para testar a validade de suas teses. Em fevereiro, ele explicou a situação de sua pesquisa para Ferdinand Lassalle:

Agora, quero te contar como está o andamento da minha ciência econômica. O trabalho está escrito. Na verdade, o texto final está em minhas mãos há alguns meses. A coisa caminha muito lentamente, porque, logo que alguém começa a apresentar matérias que têm sido objeto de estudo por anos a fio, eles começam a revelar novos aspectos e exigem ser repensados ainda mais. (MARX; ENGELS 1983, p. 268) ${ }^{36}$.

Na mesma carta, Marx lamentou mais uma vez a condição a que ele tinha que se sujeitar. Estava forçado a gastar parte do dia com artigos de jornais, ele assim escreveu: "Eu não sou senhor do meu tempo, pelo contrário sou seu escravo. Tem restado apenas à noite para a minha própria pesquisa, que por sua vez é freqüentemente interrompida por ataques da bílis ou problemas recorrentes com o figado." (MARX; ENGELS, 1983, p. 268) ${ }^{37}$.

$\mathrm{Na}$ verdade, a doença tinha acometido Marx novamente. Em janeiro de 1858 ele comunicou a Engels que estava em tratamento há três semanas: "Eu exagerei trabalhando à noite - me mantendo apenas com limonada e muito tabaco." (MARX; ENGELS, 1983, p. 247, tradução nossa) ${ }^{38}$. Em março ele estava "[...] muito doente novamente." por causa do fígado: "[...] o trabalho prolongado dia $\mathrm{e}$ noite, os numerosos pequenos desconfortos advindos das condições 
econômicas domésticas tem ultimamente sido a causa de recaídas." (MARX; ENGELS, 1983, p. 296, tradução nossa). Em abril, ele afirmou novamente:

\begin{abstract}
Tenho me sentido tão doente por causa de náuseas nesta semana que estou incapaz de pensar, ler, escrever ou, de fato, fazer qualquer coisa, com exceção dos artigos para o Tribune. Estes, é óbvio, não posso me dar ao luxo de negligenciar pois, eu devo contar com esta ninharia o mais rápido possível para evitar a falência. (MARX; ENGELS, 1983, p. 296, tradução nossa) ${ }^{39}$.
\end{abstract}

Nesse estágio de sua vida Marx tinha desistido completamente de relações com a política organizada e relações privadas, em cartas aos seus poucos amigos remanescentes ele revelou que: “[...] eu tenho vivido como um ermitão." (MARX; ENGELS, 1983, p. 225 , tradução nossa $)^{40}$ e "[...] raramente vejo as poucas pessoas que conheço, mas em geral, não faz muita falta também." (MARX; ENGELS, 1983, p. 217, tradução nossa) ${ }^{41}$. Além do contínuo encorajamento de Engels, a recessão e sua expansão mundial também alimentou suas esperanças e o estimulou a continuar trabalhando: "Em resumo, a crise está minando o terreno como uma boa e velha toupeira." (MARX; ENGELS, 1983, p. 274, tradução nossa) ${ }^{42}$. A correspondência com Engels documenta que os eventos em andamento o contagiou com entusiasmo. Em janeiro, depois de ler as notícias de Paris no Manchester Guardian, ele afirmou: "[...] tudo parece estar correndo melhor do que o esperado." (MARX; ENGELS, 1983, p. 252 , tradução nossa) ${ }^{43}$, e no fim de março, comentando sobre os últimos desdobramentos, ele acrescentou " [...] na França, o caos continua de forma bem satisfatória. É improvável que a paz se restabeleça após o verão." (MARX; ENGELS, 1983, p. 296, tradução nossa) ${ }^{44}$. E em contraste, poucos meses antes ele havia declarado de forma pessimista que:

Depois do que aconteceu nos últimos 10 anos, qualquer idéia de mostrar aversão pelas massas assim como por indivíduos deve ter crescido a um grau que odi profanum vulgus et arceo45 tornou-se quase uma máxima obrigatória. No entanto, todos esses são, eles próprios, estágios do pensamento filisteu, que irão embora com a primeira tempestade. (MARX; ENGELS, 1983, p. 268) ${ }^{46}$.

Em maio ele afirmou com satisfação que "[...] no geral, o momento atual é bem prazeroso. A História está aparentemente, em um recomeço e os sinais de dissolução em toda parte agradam a cada 
um que não esteja curvado pela conservação deste estado de coisas atuais." (MARX; ENGELS, 1983, p. 323, tradução nossa) ${ }^{47}$.

Do mesmo modo Engels relatou a Marx com grande fervor que no dia da execução de Felice Orsini, o democrata italiano julgado pela tentativa de assassinato de Napoleão III, aconteceu em Paris um grande protesto da classe trabalhadora: "[...] em uma época de grande distúrbio é bom ver que um grande chamado é feito e $100 \mathrm{mil}$ pessoas respondem 'presente'." (MARX; ENGELS, 1983, p. 289290, tradução nossa) $)^{48}$. Em vista dos possíveis desdobramentos revolucionários, ele também estudou o tamanho das tropas francesas e avisou Marx que para vencer teria sido necessário formar sociedades secretas dentro do exército, ou como em 1848, para que a burguesia se posicione contra Bonaparte. Por fim, ele previu que a separação da Hungria e Itália e as insurreições eslavas teriam atingido a Áustria violentamente, o velho bastião reacionário, e que, somando-se a isto tudo, um contra ataque generalizado teria espalhado a crise para todas as grandes cidades e distritos industriais. Em outras palavras, ela estava certo que "[...] afinal de contas, vai ser uma luta dura." (MARX; ENGELS, 1983, p. 289, tradução nossa) ${ }^{49}$. Levado pelo otimismo Engels diminuiu suas montarias, desta vez com um objetivo em vista; conforme ele escreveu a Marx:

Ontem, eu levei meu cavalo para um obstáculo e coloquei o mesmo
a 5 pés e várias polegadas de altura: o mais alto que eu já saltei[...]
quando voltarmos para a Alemanha, nós certamente teremos uma
lição ou mais para dar à cavalaria prussiana. Aqueles senhores te-
rão dificuldade para se igualar a mim. (MARX; ENGELS, 1983, p.
265 , tradução nossa) $)^{50}$.

A resposta foi com dada com grande satisfação: "Eu congratulo pela sua performance com cavalos. Mas não faça muitos saltos de quebrar o pescoço. Eu não creio que a cavalaria é a especialidade da qual virá os seus maiores serviços para a Alemanha." (MARX; ENGELS, 1983, p. 266, tradução nossa) ${ }^{51}$.

Por outro lado, a vida de Marx enfrentou mais complicações à frente. Em março, Lassalle o informou que o editor Franz Duncker de Berlim tinha concordado em publicar seu trabalho em várias etapas, mas as boas notícias paradoxalmente transformaram-se em um outro fator desestabilizador. Uma nova razão para preocupação a se juntar às outras - ansiedade - conforme descrição em uma série de 
boletins médicos endereçados a Engels, desta vez escritos por Jenny von Westphalen:

Seu fígado e bilis estão novamente num estado de revolta [...] A piora de sua condição é em grande parte atribuída ao cansaço mental e agitação que agora, depois da conclusão do contrato com os editores estão maiores do que nunca e aumentando diariamente já que ele considera praticamente impossível concluir o trabalho. (MARX; ENGELS, 1983, p. 569, tradução nossa) ${ }^{52}$.

Durante todo o mês de abril, Marx foi atacado pela mais virulenta dor causada pela bílis que ele já sofrera e não conseguia trabalhar de maneira alguma. Ele se concentrou exclusivamente nos artigos para o New York Tribune; estes eram indispensáveis a sua sobrevivência, e ele tinha que ditá-los a sua esposa que estava "[...] cumprindo inteiramente o papel de secretária." (MARX; ENGELS, 1983 , p. 125 , tradução nossa) ${ }^{53}$. Tão logo ele foi capaz de segurar uma caneta, informou a Engels que o motivo de seu silêncio se devia a sua incapacidade de escrever. Isto era visível "[...] não apenas no sentido literário, mas literalmente falando." (MARX; ENGELS, 1983, p. 309) ${ }^{54}$. Ele também afirmou que "[...] a urgência contínua de se concentrar no trabalho combinada com a incapacidade de produzir contribuía para agravar a doença." (MARX; ENGELS, 1983, p. 309 $)^{55}$. Sua situação ainda era muito ruim. "Eu não consigo trabalhar. Se eu escrever por duas horas tenho que me deitar com dores por dois dias. Eu espero, que esta terrível situação chegue ao fim na próxima semana. Isto não poderia ter acontecido em pior hora. Obviamente, durante o inverno, eu fiz trabalho extra à noite. Hinc illae lacrimae." ${ }^{56}$ (MARX; ENGELS, 1983, p. 309, tradução nossa) ${ }^{57}$.

Marx tentou lutar contra a sua enfermidade, porém depois de tomar muitos remédios sem resultar em nenhum benefício oriundo deles, resignou-se a seguir o conselho do médico que pedia para mudar de ambiente por uma semana e "[...] parar com o trabalho intelectual por um tempo." (MARX; ENGELS, 1983, p. 321) ) $^{58}$. Então ele decidiu visitar Engels, a quem ele anunciou: "Deixei de lado minhas obrigações." (MARX; ENGELS, 1983, p. 312) ${ }^{59}$. Naturalmente, durante esses 20 dias em Manchester, ele continuou trabalhando: escreveu um capítulo d'O Capital e as últimas páginas dos Grundrisse. 


\title{
3 LUTANDO CONTRA A SOCIEDADE BURGUESA
}

Mais uma vez de volta a Londres Marx deveria ter finalizado o texto para enviá-lo aos editores, mas, embora ele estivesse atrasado, ele ainda atrasou o esboço. Sua natureza crítica ganhou a competição no confronto com suas necessidades. Assim, ele informou Engels:

\begin{abstract}
Durante a minha ausência foi publicado em Londres um livro escrito por Maclarem cobrindo toda a história do dinheiro, o qual, de acordo com avaliação da The Economist é de alto nível. O livro não chegou à biblioteca ainda[...] Obviamente eu preciso lê-lo antes de escrever o meu. Por isso, enviei minha esposa até o editor na cidade, mas para nossa infelicidade, descobrimos que ele custava 9/6 libras, mais do que tudo que temos. Portanto, eu ficaria muito agradecido se você pudesse me enviar uma ordem de pagamento nesse valor. Provavelmente não haverá nada de novo para mim nesse livro, mas com o barulho que a The Economist tem feito sobre ele, e as resenhas que eu mesmo li, minha consciência teórica não me permitirá prosseguir sem antes examiná-lo. (MARX; ENGELS, 1983, p. 317, tradução nossa) ${ }^{60}$.
\end{abstract}

Este resumo é muito revelador. A periculosidade das resenhas no The Economist para a paz familiar; enviando sua esposa ao City (o centro financeiro de Londres) em uma missão para tratar com dúvidas teóricas; o fato de que suas economias não eram suficientes para sequer comprar um livro; as solicitações frequentes ao seu amigo em Manchester que requeria atenção imediata: o que pode melhor descrever a vida de Marx naqueles anos e particularmente do que era capaz sua consciência teórica?

Além do seu temperamento complexo, a saúde precária e a pobreza, seus inimigos do dia a dia, contribuíam para atrasar a conclusão de seu trabalho ainda mais. Sua condição física piorou novamente, conforme Engels foi informado: "[...] a doença da qual eu sofria antes de deixar Manchester, novamente tornou-se crônica, persistindo por todo o verão, de modo que qualquer tanto que eu escreva me custa um esforço tremendo." (MARX; ENGELS, 1983, p. 341, tradução nossa) ${ }^{61}$. Além de tudo isso, aqueles meses foram marcados por uma preocupação econômica insuportável que o forçou a viver permanentemente com o "[...] espectro de uma catástrofe definitiva." (MARX; ENGELS, 1983, p. 328, tradução nossa) ${ }^{62}$. Tomado pelo desespero novamente, em julho, Marx enviou uma carta 
para Engels que realmente testemunha a extrema situação na qual ele estava vivendo:

É necessário que juntemos esforços para ver se alguma coisa pode ser feito para sair dessa situação, pois ela tornou-se absolutamente insustentável. Isto já resultou na minha completa incapacidade de fazer qualquer trabalho, em parte porque eu tenho perdido a maior parte do tempo de um lado para o outro em tentativas infrutíferas para levantar dinheiro e parcialmente porque a força da minha capacidade de abstração - devido, talvez, a minha má condição física - não consegue dar conta das lamúrias domésticas. Minha esposa está tendo ataques de nervo por conta dessa miséria [...] Portanto, a coisa toda se resume no fato de que o pouco que entra em casa nunca é suficiente para o próximo mês, mal é o bastante para reduzir as dívidas [...] assim, esta miséria é apenas adiada por semanas pelas quais há que se virar de um jeito ou de outro. [...] nem mesmo o leilão de meus bens domésticos seria suficiente para satisfazer os credores da vizinhança e assegurar um descanso em isolamento. A manutenção de boas aparências que temos mantido tem sido o único meio de evitar o colapso. Se da minha parte eu não ligaria a mínima se vivesse em Whitechapel (área em Londres onde a maioria da classe trabalhadora vivia à época) desde que eu possa finalmente assegurar uma hora de paz na qual eu possa fazer o meu trabalho. Porém, vendo a condição de minha esposa agora, uma mudança repentina assim poderia trazer graves consequências e não seria apropriado para as meninas nessa fase de crescimento [...] eu não desejaria ao meu pior inimigo passar pelas dificuldades nas quais eu me encontro amarrado nas últimas oito semanas, ressentido das inúmeras frustrações que estão arruinando o meu intelecto e destruindo a minha capacidade de trabalhar. (MARX; ENGELS, 1983, p. 328-231, tradução nossa) $)^{63}$.

Em que pese o seu estado de extrema pobreza, Marx não deixou que a precariedade de sua situação o vencesse e, no que diz respeito à sua intenção de finalizar sua obra, ele comentou com seu amigo Joseph Weydemeyer: "Eu preciso perseguir meu objetivo a qualquer custo e não deixar que a sociedade burguesa me converta em uma maquina de fazer dinheiro." (MARX; ENGELS, 1983, p. 374, tradução nossa ${ }^{64}$.

Enquanto isto, a crise econômica cedia e em breve o mercado recuperava seu funcionamento normal. Na verdade, em agosto um Marx entristecido recorreu a Engels: "[...] nas últimas semanas o otimismo tomou conta do mundo novamente." (MARX; ENGELS, 1983, p. 338, tradução nossa) ${ }^{65}$; e Engels, refletindo sobre a forma na qual a superprodução de mercadorias tinha sido absorvida, afirmou: 
"[...] nunca antes uma inundação assim, fora drenada dessa maneira tão rapidamente." (MARX; ENGELS, 1983, p. 343, tradução nos$\mathrm{sa}{ }^{66}$. A certeza de que a revolução estava na próxima esquina, que os inspirou por todo o outono de 1856 e encorajou Marx a escrever os Grundrisse, estava dando lugar a mais amarga desilusão: "[...] não há guerra. Tudo é burguês." (MARX; ENGELS, 1983, p. 360, tradução nossa) ${ }^{67}$. E enquanto Engels se punha duramente contra o "[...] crescente aburguesamento do proletariado inglês." um fenômeno que, em sua opinião, levaria o pais líder em exploração a ter "[...] um proletariado burguês ao lado da burguesia." (MARX; ENGELS, 1983, p. 343 , tradução nossa) ${ }^{68}$. Marx se ateve a cada evento, até mesmo ao menos importante, até o fim: "[...] apesar da onda otimista impulsionada pelo comércio mundial [...] ao menos serve de consolação que a Revolução tenha começado na Rússia, pois considero a convocação dos 'notáveis' a São Petersburgo como sendo precisamente o início." (MARX; ENGELS, 1983, p. 345, grifo do autor?) ${ }^{69}$. Suas esperanças também se voltaram para a Alemanha: "[...] na Prússia as coisas estão piores do que estavam em 1847.", e também para a burguesia tcheca em sua luta por independência nacional: "[...] movimentos excepcionais estão marchando entre os eslavos, especialmente na Boêmia, que embora seja contra-revolucionária, ainda produz fermento para a mobilização." (MARX; ENGELS, 1983, p. $345)^{70}$. Finalmente, como se tivessem sido traídos, ele amargamente afirmou: "Não fará mal nenhum aos Franceses verem que, mesmo sem eles, o mundo se move." (MARX; ENGELS, 1983, p. 345) ${ }^{71}$.

Porém, Marx teve que se resignar diante da evidência: a crise não provocou os efeitos sociais e políticos que ele e Engels haviam previsto com tanta certeza. Contudo, ele ainda estava fortemente convencido que era apenas uma questão de tempo antes que a revolução na Europa irrompesse e que o problema, se de fato houvesse algum, seria quais cenários a mudança econômica teria provocado. Portanto, ele escreveu para Engels fazendo um tipo de avaliação política sobre os últimos acontecimentos e uma reflexão sobre os desdobramentos futuros:

Não podemos negar que a sociedade burguesa experimentou pela
segunda vez sua volta ao século XVI, um século que, eu espero,
soará os dobres de finado do mesmo modo que o primeiro sucum-
biu em seu tempo. A verdadeira tarefa da sociedade burguesa é a
criação do mercado mundial, ou ao menos da estrutura adequada
ao seu funcionamento, e da produção baseada no mercado. Já que 


\begin{abstract}
o mundo é redondo, me parece que a colonização da Califórnia e da Austrália e abertura da China e do Japão parece ter completado esse processo. A pergunta difícil para nós respondermos é a seguinte: Ela não irá morrer nestes pequenos recantos do mundo, já que o desenvolvimento da sociedade burguesa está apenas começando nestas áreas tão vastas? (MARX; ENGELS, 1983, p. 347, tradução nossa $)^{72}$.
\end{abstract}

Estas reflexões incluem duas das mais significativas previsões de Marx: uma delas correta o levou a intuir, melhor que a seus contemporâneos, a escala mundial do desenvolvimento do capitalismo; e uma errada, relacionada à crença de uma revolução proletária inevitável na Europa.

As cartas endereçadas a Engels contêm a crítica ferina de Marx sobre todos aqueles que eram seus adversários políticos no campo progressista. Muitos foram alvos juntamente com um de seus favoritos, Pierre-Joseph Proudhon, a principal figura do tipo de socialismo dominante na França, que Marx considerava como falso irmão do qual o comunismo precisava se livrar (MARX; ENGELS, 1983 , p. 374) ${ }^{73}$. Marx se divertia, vez ou outra, com uma relação de rivalidade com Lassalle, um exemplo disso foi quando ele recebeu o último livro de Lassalle Heráclito, O filosófo das Trevas, descrito por Marx como uma "[...] mistura de tolices." (MARX; ENGELS, 1983 , p. 258 , tradução nossa ${ }^{74}$. Em setembro de 1858, Giuseppe Mazzini publicou seu novo Manifesto no jornal Pensiero ed Azione (Pensamento e Ação), porém Marx, que não tinha qualquer dúvida sobre ele, afirmou: "[...] o mesmo idiota de sempre." (MARX; ENGELS, 1983, p. 346) $)^{75}$. Ao invés de analisar os motivos da derrota de 1848-9, Mazzini "[...] ocupa-se em divulgar a panacéia para a cura da [...] paralisia política da migração revolucionária." (MARX, 1980, p. 37). Ele também criou uma mobilização contra Julius Frobel, um membro do Câmara de Frankfurt em 1848-9 e típico representante dos democratas alemães, que tinha ido para o exterior e se distanciado da vida política "[...] depois que eles conquistaram o pão e o queijo, todos esses safados procuram um pretexto obscuro (blasé) para dizer adeus a luta." (MARX; ENGELS, 1983, p. 356) ${ }^{76}$. Por último, como sempre muito irônico, ele ridicularizou a atividade revolucionária de Karl Blind, um dos leaders dos imigrantes alemães em Londres:

Ele arranja dois conhecidos em Hamburgo para enviar cartas (escritas por ele mesmo) para jornais ingleses nos quais é mencionado 
o barulho criado pelos seus panfletos anônimos. Então seus amigos relatam em jornais alemães o burburinho feito na imprensa inglesa. Isto, como você pode ver, é que significa ser um homem de ação de verdade. (MARX; ENGELS, 1983, p. 351, tradução nossa) ${ }^{77}$.

O engajamento político de Marx tinha uma natureza diferente. Ao mesmo tempo em que nunca desistia de lutar contra a sociedade burguesa, ele também se mantinha consciente de seu papel principal nesta luta, que era o de desenvolver uma crítica do modo capitalista de produção por meio de um rigoroso estudo da economia política e uma permanente análise dos eventos econômicos. Por esta razão durante o período de baixa da luta de classes, ele decidiu usar suas energias da melhor forma possível mantendo distância de conspirações inúteis e das intrigas pessoais nas quais a competição política se resumia naquele período: "Desde o julgamento em Colônia (aquele contra os comunistas em 1853), eu me retirei completamente para me dedicar aos meus estudos. Meu tempo era precioso demais para ser desperdiçado em empreitadas infrutíferas e contendas inúteis." (MARX; ENGELS, 1983, p. 374) ${ }^{78}$. Na verdade, em que pese estar soterrado de problemas, Marx continuou a trabalhar, e publicou seu livro Uma contribuição à crítica da economia política: primeira parte em 1859 pelo qual os Grundrisse havia sido o campo inicial de experimentação. Marx terminou o ano de 1858 do mesmo modo que os anos anteriores, conforme sua esposa Jenny escreveu: "[...] 1858 não foi um ano bom, mas também não foi ruim, foi um ano em que os dias simplesmente passavam completamente sem novidade. Comendo e bebendo, escrevendo artigos, lendo jornais e fazendo caminhadas: a nossa vida se resumia a isto." (MARX, 1970, p. 224). Dia após dia, mês após mês, anos após ano, Marx continuou trabalhando na sua obra pelo resto da vida. Ele elaborou os esboços dos Grundrisse e de muitos outros volumosos manuscritos trabalhando na preparação d' O Capital com uma luta implacável e com uma certeza inabalável de que sua vida pertencia ao socialismo, um movimento pela emancipação de milhões de homens e mulheres.

\section{REFERENCIAS}

HORACE. Odes and Epodes. Ann Arbor: University of Michigan Press, 1994.

MARX, J. Umrisse eines bewegten Lebens. In: BEBEL, A. et al. Mohr und General: erinnerungen an Marx und Engels. Berlin: Dietz Verlag, 1970. 
. Mazzini’s New Manifesto. In: MARX, K.; ENGELS, F. Marx and Engels Collected Works: volume 16 - Letters 1858-60. London: Lawrence and Wishart, 1980.

. The Bourgeoisie and the Counter-Revolution. In: MARX, K.;

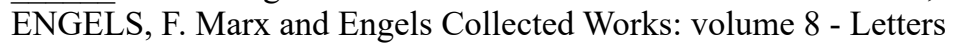
1848-49. London: Lawrence and Wishart, 1977. Articles from Neue Rheinische Zeitung

; ENGELS, F. Marx and Engels Collected Works: volume 40 Letters 1856-59. London: Lawrence and Wishart, 1983.

; $\quad$. Marx and Engels Collected Works: volume 49 -

$\overline{\text { Letters }} 1 \overline{890-92}$. London: Lawrence and Wishart, 2002.

TERENCE. Andria. Bristol: Bristol Classical Press, 2002.

\section{NOTAS:}

1 Artigo traduzido por Ronaldo da Silva, mestre em Geografia e professor assistente do Curso de Geografia do Campus de Catalão da Universidade Federal de Goiás (UFG), e revisado por Ricardo Rodrigues Alves de Lima a partir do livro MUSTO, M. (Ed.). Karl Marx's Grundrisse: foundations of the Critique of Political Economy 150 years later. London/New York: Routledge, 2008. pág. 149-161.

2 Traduções citadas no texto foram feitas pelo próprio autor.

3 De acordo com a esposa de Marx, esta mudança tornara-se absolutamente necessária: pois "[...] como todos estavam se tornando filisteus, não poderiámos continuar vivendo como boêmios (da Boêmia).” (MARX, 1970, p. 223, tradução nossa).

4 Marx para Engels, 26 de setembro de 1856.

5 Engels para Marx, 26 de setembro 1856.

6 Marx para Engels, 20 de Janeiro de 1857.

7 Marx para Engels, 2 de abril 1858

8 Marx para Engels, 18 de março de 1857

9 Marx e Engels, 23 de janeiro de 1857.

${ }^{10}$ Marx e Weydemeyer, 1 de fevereiro de 1859.

${ }^{11}$ Marx para Engels, 31 de outubro de 1857.

${ }^{12}$ Marx para Engels, 8 dezembro de 1857.

${ }^{13}$ Marx para Engels, 13 de novembro de 1857.

${ }^{14}$ Marx para Engels, 22 de fevereiro de 1857.

${ }^{15}$ Marx para Engels, 22 de fevereiro de 1858.

${ }^{16}$ Friedrich Engels a Hermann Schlüter, 29 de janeiro de 1891 - Embora eles tenham feito algumas considerações interessantes, Engels definiu o trabalho para a enciclopédia como um "[...] trabalho meramente comercial [...] que poderia seguramente permanecer enterrado.” (MARX; ENGELS, 2002, p. 113).

${ }^{17}$ Marx para Engels, 8 dezembro de 1857. 
${ }^{18}$ Marx para Engels, 28 de Janeiro 1858.

${ }^{19}$ Marx para Engels, 22 de Fevereiro 1858.

${ }^{20}$ Marx para Engels, 22 de maio de 1857.

${ }^{21}$ Marx para Engels, 8 de julho 1857.

22 Engels para Marx, 11 de julho de 1857.

${ }^{23}$ Marx para Engels, 14 de janeiro de 1858. Na edição Marx and Engels Collected Works (MECW), esta carta está datada de forma errada como sendo de 16 de janeiro de 1858.

${ }^{24}$ Marx e Engels, 15 de agosto de 1857.

${ }^{25}$ Marx para Engels 14 de janeiro de 1858.

${ }^{26}$ Apesar de ainda não existir uma edição em português desta obra, publicada pela primeira vez na União Soviética em 1939-41, traduz-se por Elementos fundamentais de crítica da economia política (Rascunhos). Nota do comitê editorial de Antítese.

${ }^{27}$ Marx para Engels, 8 de Dezembro 1857.

${ }^{28}$ Engels para Marx, 29 de Outubro de 1857.

29 Engels para Marx, 15 de novembro de 1857.

${ }^{30}$ Engels para Marx, 31 de dezembro de 1857.

${ }^{31}$ Jenny Marx to scharmm, 8 de dezembro de 1857.

${ }^{32}$ Marx para Engels, 5 de Janeiro 1858.

${ }^{33}$ Engels para Marx, 6 de Janeiro 1858.

${ }^{34}$ Marx para Engels, 1 de fevereiro de 1858.

35 Marx para Engels, 11 de janeiro de 1858.

${ }^{36}$ Marx para Lassalle, 22 de fevereiro de 1858.

${ }^{37}$ Marx para Lassalle, 22 de fevereiro de 1858.

${ }^{38}$ Marx para Engels, 14 de janeiro de 1858.

${ }^{39}$ Marx para Engels, 2 de abril de 1858.

${ }^{40}$ Marx para Lassalle, 21 de dezembro de 1857.

${ }^{41}$ Marx para Schramm, 8 de dezembro de 1857.

${ }^{42}$ Marx para Engels, 22 de fevereiro de 1858.

${ }^{43}$ Marx para Engels, 23 de janeiro de 1858.

${ }^{44}$ Marx para Engels, 29 de março de 1858.

${ }^{45} \mathrm{Tr}$ "Eu odeio e evito a multidão vulgar." (HORÁCIO, 1994, p. 127).

${ }^{46}$ Marx para Lassalle, 22 de fevereiro de 1858.

${ }^{47}$ Marx para Lassale, 31 de maio de 1858.

${ }^{48}$ Engels para Marx, 17 de março de 1858.

49 Engels para Marx, 17 de março 1858.

${ }^{50}$ Engels para Marx, 11 de fevereiro de 1858.

${ }^{51}$ Marx para Engels, 14 de Fevereiro de 1858.

52 Jenny Marx para Engels, 9 de abril de 1858.

${ }^{53}$ Marx para Engels, 23 de abril de 1857.

${ }^{54}$ Marx para Engels, 29 de abril de 1858. 


\section{Marcelo Musto}

${ }^{55}$ Marx para Engels, 29 de abril de 1858.

${ }^{56} \mathrm{Tr}$ "Por isto aquelas lágrimas." ( TERENCIO, 2002, p. 99).

${ }^{57}$ Marx para Engels, 29 de abril 1858.

${ }^{58}$ Marx para Lassalle, 31 de maio de 1858.

${ }^{59}$ Marx para Engels, 1 de maio de 1858.

${ }^{60}$ Marx para Engels, 31 de maio de 1858.

${ }^{61}$ Marx para Engels, 21 de setembro de 1858.

${ }^{62}$ Marx para Engels, 15 de julho de 1858.

${ }^{63}$ Marx para Engels, 15 de julho de 1858.

${ }^{64}$ Marx para Weydemeyer, 1 de fevereiro de 1859.

${ }^{65}$ Marx para Engels, 13 de agosto de 1858.

${ }^{66}$ Engels para Marx, 7 de outubro de 1858.

${ }^{67}$ Marx para Engels, 11 de dezembro de 1858.

${ }^{68}$ Engels para Marx, 7 de outubro de 1858.

${ }^{69}$ Marx para Engels, 8 de outubro de 1858.

${ }^{70}$ Marx para Engels, 8 de outubro de 1858.

${ }^{71}$ Marx para Engels, 8 de outubro de 1858.

${ }^{72}$ Marx para Engels, 8 de outubro de 1858.

${ }^{73}$ Marx para Weydemeyer, 1 de fevereiro de 1859

${ }^{74}$ Marx para Engels, 1 de Fevereiro de 1858

${ }^{75}$ Marx para Engels, 8 de Outubro de 1858.

${ }^{76}$ Marx para Engels, 24 de novembro 1858.

${ }^{77}$ Marx para Engels, 2 de novembro de 1858.

${ }^{78}$ Marx para Weydemeyer, 1 de fevereiro 1859. 